\title{
Weed Vegetation in Spring Wheat Crops in the Southeast of Western Siberia (On the Example of Kemerovo Region)
}

\author{
Ekaterina KONDRATENKO ${ }^{1 *}$, Elena EGUSHOVA ${ }^{1}$, Alexey STAROVOITOV ${ }^{2}$, \\ Elena STAROVOITOVA ${ }^{2}$, Iraida SERGEEVA ${ }^{1}$, and Ekaterina ROTKINA ${ }^{1}$ \\ ${ }^{1}$ Kuzbass State Agricultural Academy, Kemerovo, Russian Federation \\ ${ }^{2}$ Branch of Russia Agricultural Center in the Kemerovo Region, Kemerovo, Russian Federation \\ * Correspondence: agriculture@ksai.ru
}

\begin{abstract}
Nowadays one of the most important and difficult problems to be solved in crop production is the controlling of weeds. The phytosanitary situation in terms of weediness is still difficult despite the fact that over the past five years there has been a tendency to reduce sown areas and weediness of fields allocated for spring wheat and an increase in the volume of chemical treatment. The article presents the results of studies on the species composition, the number of weeds in spring wheat crops for 29 years of research (1989-2018) in Kemerovo region. It has been established that the majority of weeds growing in spring wheat crops are spring crops (50\%) - Stellariamedia L., Echinochloacrus-galli L., Setariaviridis L., Amaranthusalbus L., etc. There is a large proportion of root shoots (Convolvulus arvensis Murr., Cirsiumarvense L., Sonchusarvensis L.). The predominant type of weediness in the main areas of wheat sowing is mixed such as offset weediness. The appearance of new species of weeds such as Equisetumarvense L., Erigeroncanadensis L., Solanumnigrum L. has been revealed in the last 10 years. An analysis of the weediness of wheat crops showed that, despite constant chemical weeding by herbicides, the percentage of weediness of crops by ephemeral offset weeds such as flowering creeping thistle (Girsiumarvense L.) and field sow thistle (Sonchusarvensis L.) remains unchanged. The share of such weed plants as field horsetail (Equisetumarvense L.), Tatar buckwheat (Fagopyrumtataricum L.), common flax (Linariavulgaris Mill., etc.), leafy spurge (Euphorbiavirgata) had increased by 2018.
\end{abstract}

Keywords: wheat, species, abundance of weed component, acreage, herbicides.

\section{Introduction}

Weeds belong to the main groups of harmful organisms at spring wheat cultivation in Western Siberia. Despite the high importance of the West Siberian grain belt for crop production in Russia, its weed communities are largely unknown [1, p. 249].

Dolzhenko V. I., N.G. Vlasenko, A.N. Vlasenko, N.A. Korotkikh and other Siberian scientists [2, p. 124] studied the weediness of wheat crops in Western Siberia. The authors convincingly argue that at present $50-60 \%$ of arable land has weed growth in a strong and medium degree in this region. An increase in the number and biomass of weeds to a certain level causes a decrease in the biological productivity of wheat with weak 
weediness by $5-10 \%$, with an average weediness by $20-30 \%$ and strong weediness by $40-70 \%$.

In their opinion, the main reasons for the high weediness of the fields are the low level of crop cultivation, the imperfection of organizational and economic measures, the minimization of the complex of agrotechnical measures, insufficient attention to a systematic approach to weed control in crop rotation and the mismatch between the action spectrum of the applied herbicides and the species composition of weeds. Following their comprehensive research on weeds, scientists argue that weeds obscuring the soil and slowing down crop growth often inhibit photosynthesis and lower the soil temperature by $1.5-4^{\circ} \mathrm{C}$. Under Siberian conditions such a decrease in soil temperature negatively affects the growth and development of cultivated plants.

The studies carried out in the Trans-Ural steppe zone of the Republic of Bashkortostan [3, p. 26] made it possible to establish that xerophytes and mesoxerophytes are replaced by more mesophytic weed species in a system of zero tillage (No-till). The largest number of weeds was noted in flax and wheat crops (up to 30 species).

Some researchers argue that No-till technology may also have a negative effect on yield due to insufficient weed control [4].

UN Food and Agriculture Organization data are presented in this source [5, p. 46]. They show that annual damage from harmful organisms including weeds reaches $40 \%$ of the potential global food crop yield.

An extensive long-term study of weeds in wheat crops was carried out in the Rostov region [6, p. 140]. Researchers emphasize convincingly that a strategy for controlling weeds should be formed based on the presence of the most harmful and hardly eradicated species in crops.

V.A. Zakharenko and Iqbal at al. [7, p. 6; 8] consider that weeds are often the centers of mass distribution of pests and diseases. First, pests develop on weeds and then switch to cultivated ones. Weeds are reserves of fungal diseases. Dove-colored foxtail, field thistle, blue cornflower, white goosefoot are the reserves of root rot of spring wheat. Wheatgrass, wild oats serve as intermediate plants-hosts of stem, yellow and crown rust of grain crops.

It is proved in further studies $[9$, p. 1$]$ that the negative impact of weeds of certain species on the growth and development of crops is due to allelopathic effects. Organic substances produced by them are secreted from aboveground and underground organs and can be both inhibitors and activators of the growth of cultivated plants. In the process of studying the allelopathic effect of Boerhavia procumbens on lettuce seed growth, it showed a strong inhibitory allelopathic effect [10, p. 2169]. Viburnum grandiflorum Wall. ex $D C$ had a strong stimulating effect on the growth of lettuce seeds. The diversified allelopathic effects of plants have the potential to improve weed control. Currently, attempts are being made to control the allelopathic activity of plants by genetic engineering in order to increase the synthesis of certain active substances isolated by the roots, which will be able to resist more successfully stressful conditions for the plant.

Other researchers [11] compared the influence of weeds, which enter into competition for light, water and nutrient resources with cultivated plants with their allelopathic effect 
on growth processes. The authors found that weeds lower growth rates more than their allelopathic effect. Weed competition has reduced the yield of both crops such as ((Silybum marianum (L.) Gaertn.) and (Cynara cardunculus L.).

Studies [12] also confirm the fact that competition of weeds with cultivated plants leads to a significant decrease in crop yields and the quality of the resulting products.

It is shown in the works $[13$, p. 35] and $[14$, p. 8] that the development of any measures to prevent or kill weeds should be preceded by floristic studies to identify the species composition of weeds of a particular region as a whole and especially the main types of weed crops.

The species composition and abundance of weeds in spring wheat crops have been insufficiently studied in Kemerovo region.

The aim of the study was to determine the species composition and dynamics of the number of weeds in spring wheat crops in the south-east of Western Siberia (on the example of Kemerovo region).

\section{Conditions, Materials and Methods}

The task of this work was to determine the species, classes, family, biological group and the number of weeds in agrophytocenoses of spring wheat crops. We have summarized the results of studies over 29 years of observation. The study on the species composition and number of weeds in spring wheat crops was carried out from 1989 to 2018 in Kemerovo region.

The territory of the Kemerovo region is located in the southeastern part of the West Siberian Plain. The northern part of the region is located within the Mariinsk foreststeppe and the southern part in the steppe zone of the Kuznetsk Basin. The average duration of the period with a temperature of $+5{ }^{\circ} \mathrm{C}$ is $159-168$ days with the accumulation of the sum of active temperatures of $1600-1800{ }^{\circ} \mathrm{C}$ and the sum of annual precipitation in the mountainous part of $800 \mathrm{~mm}$, in the Kuznetsk Basin of $450 \mathrm{~mm}$, in the flat arid northwestern part of $300 \mathrm{~mm}$. Most of the precipitation falls mainly in the second half of summer) [15, p. 331].

According to data represented in this work [16, p. 211] the soil cover of the Kemerovo region is very diverse. The soils in this area are mainly leached podzolized chernozem, gray and dark gray forest soils.

Accounting of field weediness was carried out by a quantitative method. To do this, we passed each field and section along the largest diagonal and imposed an accounting frame at regular intervals at 20 points. The size of frame was $50 \times 50 \mathrm{~cm}\left(0.25 \mathrm{~m}^{2}\right)$. The number of weeds of each species was counted inside the frame. All types of weeds were taken into account during the crop examining. The surveyed areas were grouped according to the degree of weediness according to the gradation of the number of weeds (pcs / $\mathrm{m}^{2}$ ): up to 5 - very weak; 5.1-15 - weak; 15.1-50 - average; 50.1-100 - strong and more than 100 is very strong. 


\section{Results and Discussions}

The study of weeds included in the structure of agrocenosis revealed the species composition and variability of the species composition of weeds of segetal and ruderal habitats.

The analysis showed that the community of weed species in spring wheat crops totals 33 species from 22 families. The species of the following families prevail: Asteraceae families - 21.8\%; Poaceae - 12.5\%; Brassicaceae - 9.4\%. These three leading families account for 14 species (43.8\%). The rest are represented by one or two species.

An analysis of the composition of weeds by life span showed that young species predominate - $67.3 \%$ (21 species), the share of perennial species is $32.7 \%$ (11 species) of the total number of weeds. Dicotyledonous weeds account for $88.4 \%$, of which $30.1 \%$ are perennial species, $9.4 \%$ are for monocotyledonous weeds and 2 of them are perennials (Table 1 ).

In this work [17, p. 454] 5 groups of weeds were distinguished according to the degree of their specialization in tillage conditions: segetal, segetal-ruderal, ruderal-segetal, ruderal and residual plants.

Five are segetal (15.6\%), 14 are segetal-ruderal (42.3\%), 11 are ruderal-segetal (34.1\%), 3 are ruderal (8.0\%) of the total weed species. Thus, segetal and segetalruderal together account for $49.7 \%$ of the total number of species.

Table 1. Species, genus, family, biological group of weed plants in spring wheat crops of the Kemerovo region (1989-2018)

\begin{tabular}{lllc}
\multicolumn{1}{c}{ Species } & Family & Habitat & $\begin{array}{c}\text { Biological } \\
\text { group }\end{array}$ \\
\hline $\begin{array}{l}\text { Chickweed } \\
\text { Stellaria media } \text { L. }\end{array}$ & Caryophyllaceae & ruderal-segetal & Ephemera \\
\hline $\begin{array}{l}\text { Redstem filaree } \\
\text { Erodium cicutarium (L) L.Herit. }\end{array}$ & Geraniaceae & segetal-ruderal & Wintering \\
\hline $\begin{array}{l}\text { White goosefoot } \\
\text { Chenopodium album L. }\end{array}$ & Amaranthaceae & segetal-ruderal & Early spring \\
\hline $\begin{array}{l}\text { Black-bindweed } \\
\text { Fallopia convolvulus (L.) Love }\end{array}$ & Polygonaceae & ruderal-segetal & Offset \\
\hline $\begin{array}{l}\text { Tartary buckwheat } \\
\text { Fagopyrum tataricum (L.) Gaerth. }\end{array}$ & Polygonaceae & segetal & Early spring \\
\hline $\begin{array}{l}\text { Large-flowered hemp-nettle } \\
\text { Galeopsis speciosa Mill }\end{array}$ & Lamiaceae & segetal-ruderal & Early spring \\
\hline
\end{tabular}




\begin{tabular}{|c|c|c|c|}
\hline Species & Family & Habitat & $\begin{array}{l}\text { Biological } \\
\text { group }\end{array}$ \\
\hline $\begin{array}{l}\text { Wild radish } \\
\text { Raphanus raphanistrum } L \text {. }\end{array}$ & Brassicaceae & segetal-ruderal & Spring annual \\
\hline $\begin{array}{l}\text { Common wild oat } \\
\text { Avena fatua } L \text {. }\end{array}$ & Poaceae & segetal & Early spring \\
\hline $\begin{array}{l}\text { Cleavers } \\
\text { Galium aparine } L \text {. }\end{array}$ & Rubiaceae & segetal-ruderal & Early spring \\
\hline $\begin{array}{l}\text { Cockspur } \\
\text { Echinochloa crusgalli L. }\end{array}$ & Poaceae & segetal & Late spring \\
\hline $\begin{array}{l}\text { Red-root amaranth } \\
\text { Amarantus retroflexus } L \text {. }\end{array}$ & Amaranthaceae & ruderal & Late spring \\
\hline $\begin{array}{l}\text { Witchgrass } \\
\text { Panicum capillare L., } \\
\text { P. Millaceum L. }\end{array}$ & Poaceae & segetal-ruderal & Late spring \\
\hline $\begin{array}{l}\text { Foxtail } \\
\text { Setaria glauca (L.) Beauv }\end{array}$ & Poaceae & segetal-ruderal & Late spring \\
\hline $\begin{array}{l}\text { Cornflower } \\
\text { Centaurea cyanus } L .\end{array}$ & Asteraceae & segetal & Rhizomatous \\
\hline $\begin{array}{l}\text { Tufted vetch } \\
\text { Vicia cracca } L \text {. }\end{array}$ & Fabaceae & ruderal-segetal & Rhizomatous \\
\hline $\begin{array}{l}\text { Scentless false mayweed } \\
\text { Matricaria inodora } L \text {. }\end{array}$ & Asteraceae & ruderal & Wintering \\
\hline $\begin{array}{l}\text { Field pansy } \\
\text { Viola arvensis Murr. }\end{array}$ & Violaceae & ruderal-segetal & Wintering \\
\hline $\begin{array}{l}\text { Field pennycress } \\
\text { Thlaspi arvense } L .\end{array}$ & Brassicaceae & ruderal-segetal & Wintering \\
\hline $\begin{array}{l}\text { Creeping thistle } \\
\text { Cirsium arvense (L.) Scop. }\end{array}$ & Asteraceae & segetal-ruderal & Offset \\
\hline $\begin{array}{l}\text { Field bindweed } \\
\text { Convolvulus arvensis } L \text {. }\end{array}$ & Convolvulaceae & segetal-ruderal & Offset \\
\hline $\begin{array}{l}\text { Field milk thistle } \\
\text { Sonchus arvensis } L \text {. }\end{array}$ & Asteraceae & segetal-ruderal & Offset \\
\hline $\begin{array}{l}\text { Bittercress } \\
\text { Barbarea vulgaris } R . B r .\end{array}$ & Brassicaceae & segetal-ruderal & Wintering \\
\hline $\begin{array}{l}\text { Common toadflax } \\
\text { Linaria vulgaris Mill. }\end{array}$ & Plantaginaceae & ruderal-segetal & Offset \\
\hline
\end{tabular}




\begin{tabular}{|c|c|c|c|}
\hline Species & Family & Habitat & $\begin{array}{l}\text { Biological } \\
\text { group }\end{array}$ \\
\hline $\begin{array}{l}\text { Leafy spurge } \\
\text { Euphorbia waldsteinii (Sojk) Czer. }\end{array}$ & Euphorbiaceae & ruderal-segetal & Offset \\
\hline $\begin{array}{l}\text { Couch grass } \\
\text { Agropyrum repens (L.) P.B. }\end{array}$ & Poaceae & segetal-ruderal & Rhizomatous \\
\hline $\begin{array}{l}\text { Field horsetail } \\
\text { Eguisetum arvense } L \text {. }\end{array}$ & Equisetaceae & segetal & Rhizomatous \\
\hline $\begin{array}{l}\text { Common dandelion } \\
\text { Taraxacum officinale Wigg. }\end{array}$ & Asteraceae & ruderal-segetal & Taproot \\
\hline $\begin{array}{l}\text { Wormwood } \\
\text { Artemisia absinthium L. }\end{array}$ & Asteraceae & ruderal & Taproot \\
\hline $\begin{array}{l}\text { Broadleaf plantain } \\
\text { Plantago major } L \text {. }\end{array}$ & Plantaginaceae & ruderal-segetal & Fibrous-offset \\
\hline $\begin{array}{l}\text { Marsh woundwort } \\
\text { Stachys palustris } L \text {. }\end{array}$ & Lamiaceae & segetal-ruderal & Rhizomatous \\
\hline $\begin{array}{l}{ }^{* *} \text { Turkish wartycabbage } \\
\text { Bunias orientalis } L \text {. }\end{array}$ & Brassicaceae & ruderal-segetal & Taproot \\
\hline $\begin{array}{l}\text { *Bladder campion } \\
\text { Oberna behen (L.) }\end{array}$ & Caryophyllaceae & segetal-ruderal & $\begin{array}{l}\text { Optional } \\
\text { biennial }\end{array}$ \\
\hline $\begin{array}{l}\text { Cannabis weed } \\
\text { Cannabis ruderalis Janisch. }\end{array}$ & Cannabaceae & segetal-ruderal & Late spring \\
\hline
\end{tabular}

In the conditions of the Kemerovo region, 5 segetal species of weeds in wheat crops were revealed: Avena fatua L. - empty oat, common wild oat; Echinochloa crusgalli (L.) Beauv. common cockspur, barnyard millet, Fagopyrum tataricum (L.) Gaertn. - Tatar buckwheat, Centaurea cyanus L. - blue cornflower, Eguisetum arvense L. - field horsetail.

It was established that 12 species out of the total number prevailed in the weed component over the past 5 years such as Sisymbrium loeselii, Cirsium setosum, Sonchus arvensis, Elytrigia repens, Avena fatua, Chenopodium album, Chenopodium aristatum, Amaranthus retroflexus, Fallopia convolvulus, Melandrium album, Erodium, Cannabis ruderalis. Among them 1 species (Avena fatua) is segetal; 12 species are segetal-ruderal and 2 species (Sisymbrium loeselii, Melandrium album) are ruderal-segetal.

Weeds that are classified as segetal-ruderal species are the most resistant and plentiful in crops. They account for $75 \%$ of the total number of prevailing species.

The floristic spectrum of segetal vegetation revealed by us coincides with the spectrum obtained by a number of researchers for individual territories of Siberia [18; 19, p. 3].

In this work [20, p. 591] segetal vegetation in the cultivated areas of South Srem (Serbia) was studied. The researchers found that the segetal flora consisted of 124 plant species, 
classified by 38 families. The largest number of species were species of the Asteraceae family and Poaceae family.

The research results showed that the area of weed spring wheat cultivated in the Kemerovo region as a whole increases with a relatively constant ratio of dicotyledonous and monocotyledonous weeds. The dynamics of increase in acreage for spring wheat and areas with monocotyledonous and dicotyledonous weeds (for 1989-2008) is shown in Figures 1 and 2. It was established that the increase in weediness is directly related to the increase in acreage. There was a close link between the total area of wheat and the area of weedy crops. The correlation coefficient was $r=0.94$.

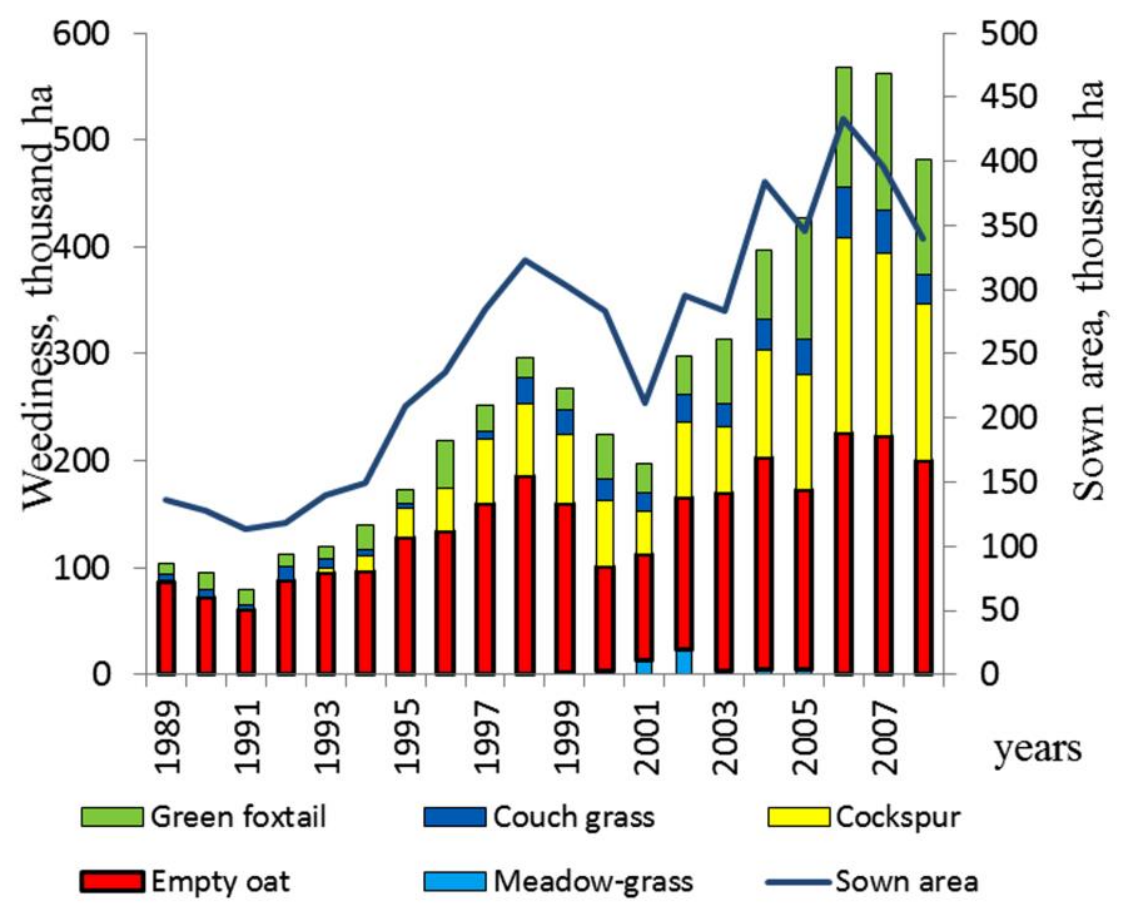

Figure 1. Dynamics of the sown area and structure of weediness of crops by monocotyledonous plants, 1989-2008

(according to the data of Kemerovo Branch of the Russian Agricultural Center)

Analysis of the data obtained during the period of research from 1989 to 2008 on the number of weeds says that the weediness of spring wheat crops varied significantly from year to year due to different meteorological conditions.

As a result of studies, it was found that the percentage of weediness by dicotyledonous perennial offset weeds such as flowering creeping thistle, field sow thistle, common flax in wheat crops remains unchanged despite constant chemical weeding.

In some years, a sharp increase or decrease in the share of some species was revealed. This could be triggered by a number of factors (weather conditions, the introduction of new sown areas). So, in 1994 an increase in the share of the dicotyledonous annual late spring weed plant such as wild buckwheat and dicotyledonous ephemeral white goosefoot and the reduction of the dicotyledonous perennial offset field bindweed and perennial rhizome weed as horsetail were observed. 
The largest percentage of weediness of the fields is accounted for by dicotyledonous perennial offset weeds of the flowering creeping thistle and field sow thistle of 11.7 and $14 \%$, respectively (Figure 2 ).

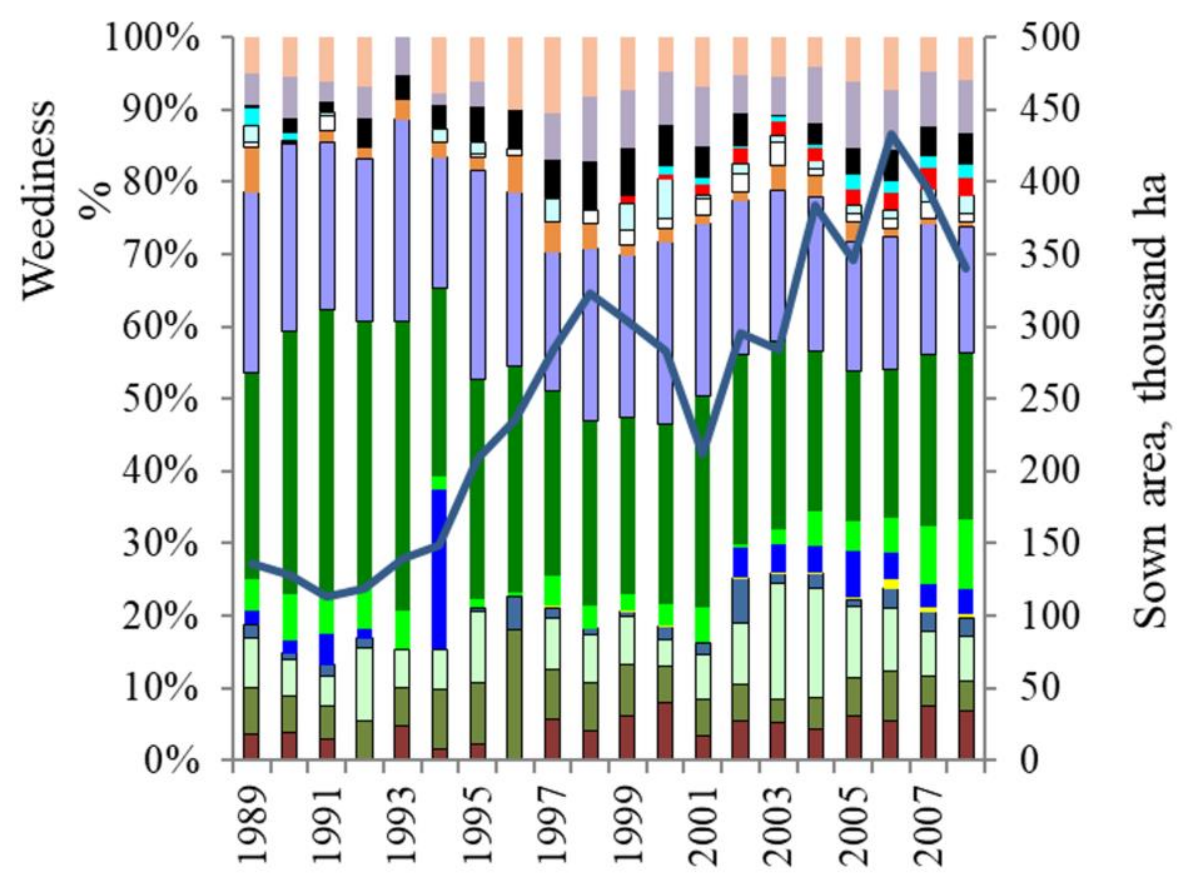

Years
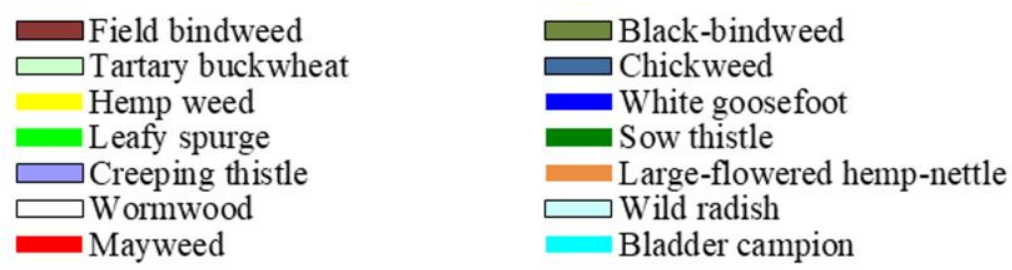

Figure 2. Dynamics of the sown area and structure of weediness of crops by dicotyledonous plants, 1989-2008

According to the agrobiological classification, most of the weeds growing in spring wheat crops in the Kemerovo region are spring crops (50\%). The share of offset weeds is high.

One of the promising areas in the development of measures for weed control is the combination of agricultural and chemical means.

The range of applied herbicides and the area of chemical treatment of crops are increasing from year to year in the Kemerovo region.

There has been an increase in the cultivated areas of spring wheat treated with herbicides. Data for the study period (1989-2018) are presented in Table 2. 
Table 2. Area sown with wheat treated with herbicides in the Kemerovo region, thousand ha (1989-2018)

\begin{tabular}{cccccc}
\hline Year & $\mathbf{1 9 8 9}$ & $\mathbf{1 9 9 0}$ & $\mathbf{1 9 9 1}$ & $\mathbf{1 9 9 2}$ & $\mathbf{1 9 9 3}$ \\
\hline $\begin{array}{l}\text { Treated with herbicides, } \\
\text { thousand ha }\end{array}$ & 44 & 28 & 20 & 12 & 14 \\
\hline Year & $\mathbf{1 9 9 4}$ & $\mathbf{1 9 9 5}$ & $\mathbf{1 9 9 6}$ & $\mathbf{1 9 9 7}$ & $\mathbf{1 9 9 8}$ \\
\hline $\begin{array}{l}\text { Treated with herbicides, } \\
\text { thousand ha }\end{array}$ & 21 & 54 & 79 & 130 & 150 \\
\hline Year & $\mathbf{1 9 9 9}$ & $\mathbf{2 0 0 0}$ & $\mathbf{2 0 0 1}$ & $\mathbf{2 0 0 2}$ & $\mathbf{2 0 0 3}$ \\
\hline $\begin{array}{l}\text { Treated with herbicides, } \\
\text { thousand ha }\end{array}$ & 149 & 121 & 125 & 137 & 177 \\
\hline $\begin{array}{c}\text { Year } \\
\text { Yreated with herbicides, }\end{array}$ & 218 & 343 & 310 & 338 & 297 \\
\hline thousand ha & $\mathbf{2 0 0 9}$ & $\mathbf{2 0 1 0}$ & $\mathbf{2 0 1 1}$ & $\mathbf{2 0 1 2}$ & $\mathbf{2 0 1 3}$ \\
\hline $\begin{array}{l}\text { Yreated with herbicides, } \\
\text { thousand ha }\end{array}$ & 351 & 168 & 277 & 260 & 331 \\
\hline $\begin{array}{l}\text { Yreated with herbicides, } \\
\text { thousand ha }\end{array}$ & $\mathbf{2 0 1 4}$ & $\mathbf{2 0 1 5}$ & $\mathbf{2 0 1 6}$ & $\mathbf{2 0 1 7}$ & $\mathbf{2 0 1 8}$ \\
\hline
\end{tabular}

In 1989, the cultivated area with herbicides was only 44 thousand hectares (32\% of the sown area). By 1999 the size of the cultivated area increased 3.4 times and amounted to 149 thousand hectares (49\% of the sown area). In 2005 almost all the crops were treated with herbicides ( $99 \%$ of the sown area of wheat). The area of cultivated crops increased by 7.8 times compared to 1989 and was 343 thousand ha.

Over the next three years, there has been a slight decrease in the share of cultivated crops. So, in 2009351 thousand hectares were cultivated (74.5\% of the cultivated area). In 2012 and 2013 the size of cultivated areas amounted to 260 and 331 thousand ha, respectively. On average, over the past five years (2014-2018) the area of spring wheat cultivated by herbicides against weeds has decreased by $14 \%$ of the area allocated for this crop (the average sown area for 5 years amounted to 274 thousand hectares and the cultivated area of 169 thousand ha). It was revealed that, despite the increase in the proportion of areas treated with herbicides during the study period, there is no tendency to increase the proportion of crops with weak weediness and the number of areas with medium and high weediness in some years even increase (Table 3). Over the study period, the proportion of areas with zero weediness varied in the range from 3.1\% (1994 level) to $15.2 \%$ (2018 level). The average value is $7.5 \%$. 
Table 3. Dynamics of changes in the area under sowing of spring wheat of varying degrees of weediness in the conditions of the Kemerovo region (1989-2018)

\begin{tabular}{|c|c|c|c|c|c|c|}
\hline \multirow{3}{*}{ Years } & \multirow{3}{*}{$\begin{array}{l}\text { Surveyed area, } \\
\text { thousand ha }\end{array}$} & \multicolumn{5}{|c|}{ The number of weeds, pcs $/ \mathrm{m}^{2}$} \\
\hline & & \multirow{2}{*}{$\begin{array}{c}\text { up to } 5 \\
\begin{array}{c}\text { weak } \\
\text { weediness }\end{array}\end{array}$} & \multirow{2}{*}{$\begin{array}{c}\text { from } 5.1 \\
\text { to } 15 \\
\begin{array}{c}\text { medium } \\
\text { weediness }\end{array}\end{array}$} & $\begin{array}{l}\text { from } 15.1 \\
\text { to } 50\end{array}$ & $\begin{array}{c}\text { from } 50.1 \\
\text { to } 100\end{array}$ & $\begin{array}{c}\text { more } \\
\text { than } \\
100\end{array}$ \\
\hline & & & & \multicolumn{3}{|c|}{$\begin{array}{c}\text { high } \\
\text { weediness }\end{array}$} \\
\hline \multirow{2}{*}{ 1989-1993 } & \multirow{2}{*}{119.7} & $\underline{42.9}^{*}$ & $\underline{35.7}$ & $\underline{28.1}$ & $\underline{11.2}$ & $\underline{1.8}$ \\
\hline & & 35.8 & 29.8 & 23.5 & 9.3 & 1.6 \\
\hline \multirow{2}{*}{ 1994-1998 } & \multirow{2}{*}{227.1} & $\underline{80.6}$ & $\underline{73.1}$ & $\underline{48.6}$ & $\underline{17}$ & $\underline{7.6}$ \\
\hline & & 35.6 & 32.2 & 21.4 & 7.5 & 3.3 \\
\hline \multirow{2}{*}{$1999-2003$} & \multirow{2}{*}{248.1} & $\underline{66.0}$ & $\underline{79.9}$ & $\underline{56.8}$ & $\underline{21.8}$ & $\underline{7.3}$ \\
\hline & & 26.6 & 32.2 & 22.9 & 8.8 & 3.1 \\
\hline \multirow{2}{*}{ 2004-2008 } & \multirow{2}{*}{347.0} & $\underline{104.5}$ & $\underline{94.5}$ & $\underline{79.7}$ & $\underline{43.0}$ & $\underline{21.8}$ \\
\hline & & 30.1 & 27.2 & 23.1 & 12.4 & 6.2 \\
\hline \multirow{2}{*}{$2009-2013$} & \multirow{2}{*}{171.8} & $\underline{75.5}$ & $\underline{47.6}$ & $\underline{31.0}$ & $\underline{14.1}$ & $\underline{3.6}$ \\
\hline & & 42.4 & 24.5 & $\underline{12.6}$ & 8.2 & 2.1 \\
\hline \multirow{2}{*}{ 2014-2018 } & \multirow{2}{*}{177.5} & $\underline{63}$ & $\underline{62.3}$ & $\underline{30}$ & $\underline{9.8}$ & \multirow{2}{*}{-} \\
\hline & & 35.5 & 35.1 & 16.9 & 5.5 & \\
\hline
\end{tabular}

* Numerator - area (thousand ha), denominator -\% of the surveyed area

The weediness of spring wheat crops in the Kemerovo region reaches an average of $87.6 \%$, including the areas with medium and high weediness (53.3\%).

Two hundred and sixty thousand ha were surveyed in 2012. Two hundred and sixty thousand ha had weeds. It is $100 \%$ of the surveyed area. The species composition of weeds in relation to 2011 had not changed and was mainly represented by cereal and perennial offset weeds. The dominant weed species in the Kemerovo region on all wheat crops are couch grass, field bindweed, field milk thistle, cleavers, cockspur, foxtail, common wild oat, red-root amaranth, white goosefoot, large-flowered hemp-nettle, Tatar buckwheat, bladder campion.

The dynamics of changes in weeds in agrocenoses of spring wheat over the past five years is shown in Figure 3. As a result of studies, it was found that dicotyledonous weeds prevail in the crops of this wheat as in previous years. By 2018 the percentage of dicotyledonous young weeds had increased and the percentage of dicotyledonous annuals had decreased. 


\section{The dynamics of classes of weeds in the Kemerovo region}

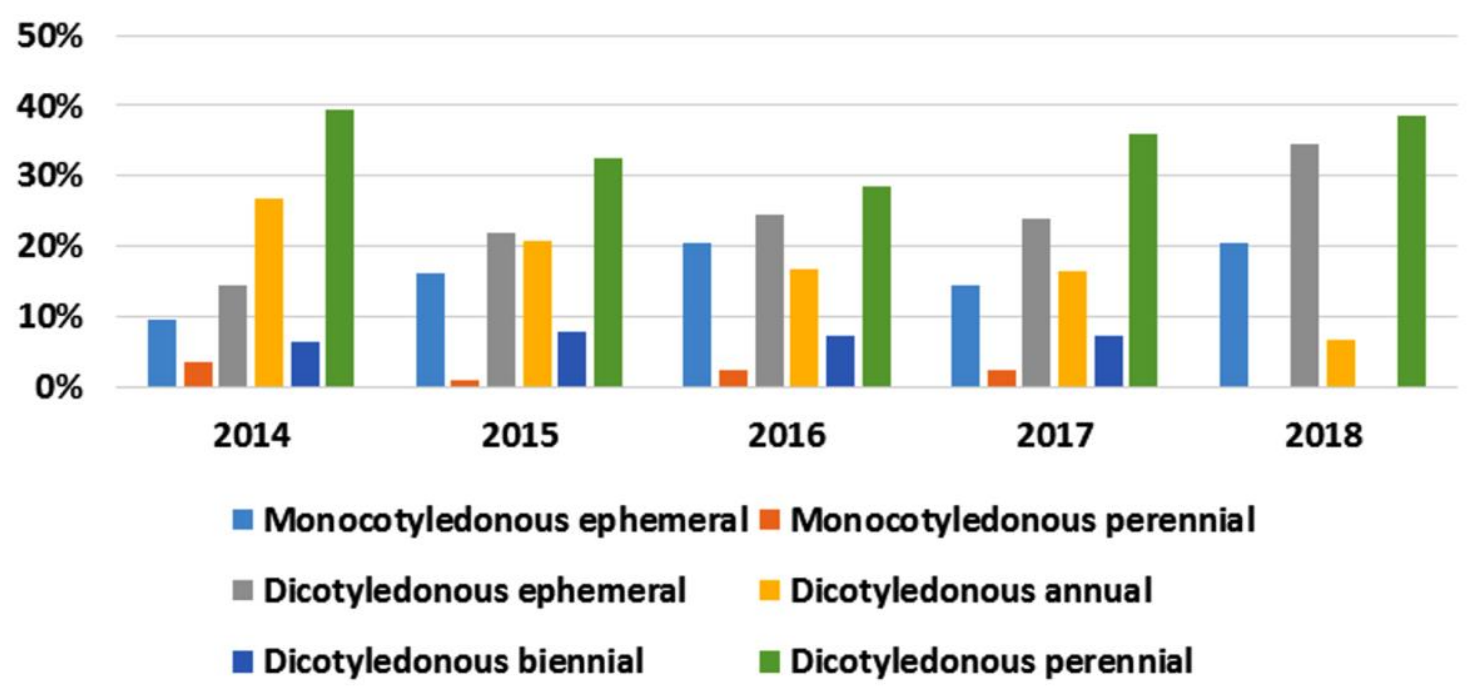

Figure 3. The dynamics of weeds classes in the Kemerovo region (2014-2018)

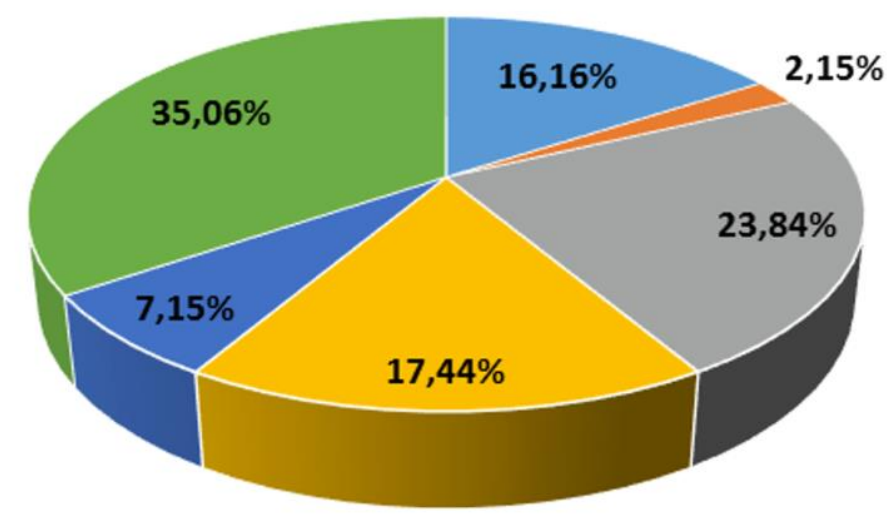

\footnotetext{
- Monocotyledonous ephemeral = Monocotyledonous perennial

- Dicotyledonous ephemeral = Dicotyledonous annual

- Dicotyledonous biennial = Dicotyledonous perennial
}

Figure 4. Class structure of weed plants for 2014-2018

From the data of Figure 4 it can be seen that $35.05 \%$ are dicotyledonous perennial weeds in the agrocenosis of wheat crops. Dicotyledonous ephemeral weeds account for $23.84 \%$. High weediness is observed in dicotyledonous annuals (17.44\%) and monocotyledonous ephemeral weeds (16.16\%).

Figure 5 shows the prevailing weed species in spring wheat crops. 

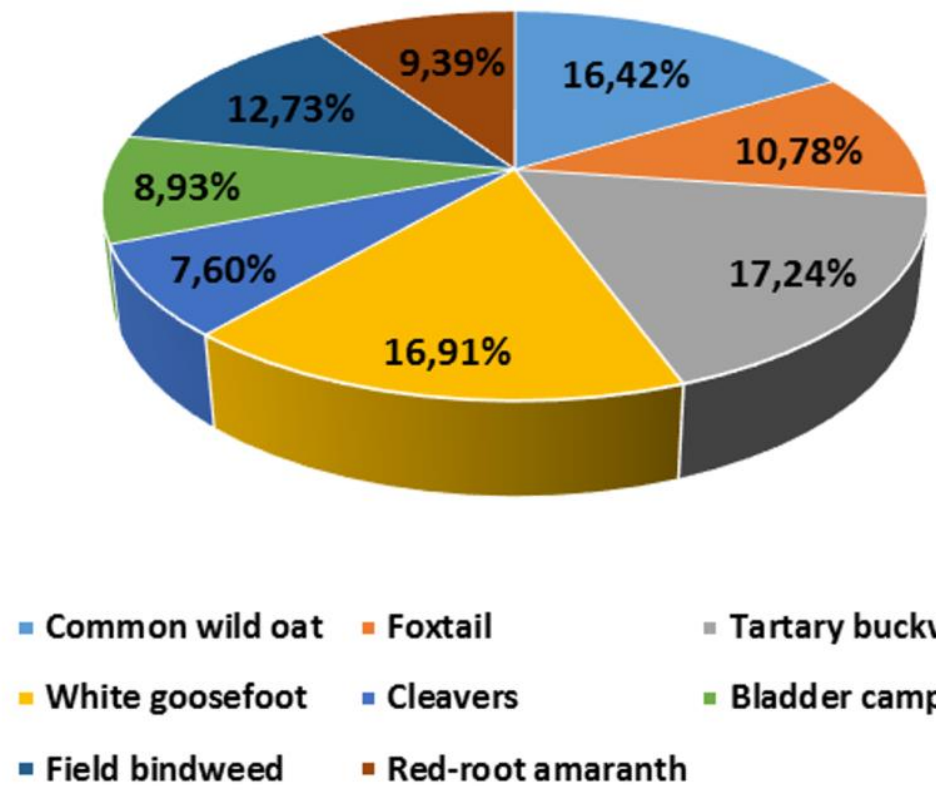

" Tartary buckwheat

- Bladder campion

- Field bindweed = Red-root amaranth

Figure 5. The structure of weeds prevailing in spring wheat in the Kemerovo region

The highest abundance indicators are inherent in Tatar buckwheat, white goosefoot. Common wild oat and foxtail also belong to common species. Red-root amaranth, cleavers and bladder campion were represented less.

Currently, weediness of crops is one of the most important and difficult problems in crop production of the Kemerovo region. Despite the fact that over the past five years there has been a tendency to reduce sown areas and weediness of fields allocated for spring wheat and an increase in the volume of chemical treatments, the phytosanitary situation in terms of weediness is still difficult. Violation of the system of agricultural technical measures for the cultivation of spring wheat, non-compliance with crop rotation, an increase in uncultivated areas - all this contributes to an increase in area weediness.

Weeds of different species grow in the fields not in isolation from each other but in certain combinations. Some of weeds prevail in these combinations, while others are found in small quantities. It is necessary to kill all types of weeds included in the combination simultaneously. If you rid fields of the prevailing weeds, those weeds that were few can be propagated.

The comprehensive weediness of spring wheat crops in the Kemerovo region with annual and perennial cereal and monocotyledonous and dicotyledonous weeds requires adequate measures for the selection of herbicides.

Weed control can be successful only when the entire range of available activities and the possibilities for their implementation are carried out in the fields. It is necessary to know the ways and patterns of weediness for successful control. This will determine the most vulnerable places in phytocenoses of weeds and will determine effective measures to control the weed component. 


\section{Conclusions}

Based on the studies, it was revealed that the following weeds predominate in wheat crops in the Kemerovo region: white goosefoot, Tatar buckwheat, common wild oat, foxtail, red-root amaranth, cleavers, bladder campion. Despite constant chemical weeding, the percentage of weediness by dicotyledonous perennial offset weeds such as flowering creeping thistle, field milk thistle, common toadflax remains unchanged. By 2018, the share of such perennial rhizome weeds as field horsetail, dicotyledonous ones as Tatar buckwheat and leafy spurge had increased. The distribution of weeds, taking into account ruderal habitats, revealed that 5 are segetal (15.6\%), 14 are segetal-ruderal (42.3\%), 11 are ruderal-segetal (34.1\%), 3 - ruderal (8.0\%) out of 33 weed species. Of the 12 species prevailing in the weed component over the past 5 years, 1 are segetal $(8.3 \%)$, 9 are segetal-ruderal (75\%), 2 are ruderal-segetal (16.7\%). The most stable and plentiful weeds in crops belong to the segetal-ruderal species. They account for $75 \%$ of the total number of prevailing species.

\section{References}

(1) Kämpf, I.; Hölzel, N.; Kiehl, K. Arable Weed Communities in the South of Western Siberia - Impoverished Species Pools Constrain Diversity despite Low Land-Use Intensity. Tuexenia 2016, 36, 249-270. https://doi.org/10.14471/2016.36.01.

(2) Dolzhenko, V. I.; Vlasenko, N. G.; Vlasenko, A. N.; Korotkikh, N. A.; Teplyakova, O. N.; Kulegin, O. V.; Slobodchikov, A. A.; Kudashkin, P. I.; Lyubimets, Yu. V.; Garkusha, A. A.; et al. Zonal Systems for Protecting Spring Wheat from Weeds, Diseases and Pests in Western Siberia (in Russian); Siberian Research Institute of Agriculture and Chemicalization of Agriculture: Novosibirsk, 2014.

(3) Khasanova, G. R.; Safin, H. M.; Yamalov, S. M. Estimation of Infestation Level of Agrophytocenosis at the Zero System of Tillage (No-till) (in Russian). Dostizheniya nauki i tekhniki APK (Achievements of Science and Technology of AIC) 2017, 31 (11), 26-30.

(4) Page, K. L.; Dang, Y. P.; Dalal, R. C.; Reeves, S.; Thomas, G.; Wang, W.; Thompson, J. P. Changes in Soil Water Storage with No-Tillage and Crop Residue Retention on a Vertisol: Impact on Productivity and Profitability over a 50 Year Period. Soil and Tillage Research 2019, 194, 104319. https://doi.org/10.1016/j.still.2019.104319.

(5) Conova, A. M.; Samoilov, L. N. Removal of Nutrients Cultural and Weeds in the Crop Rotation (in Russian). Agrochemistry 2015, 5, 46-53.

(6) Tokarev, E. V.; Khilevsky, V. A.; Makhankava, T. A. Long-Term Monitoring of Weeds in Winter Wheat Crops in the Rostov Region (in Russian). Priority Areas for the Development of Science and Education 2015, 3 (6), 140-152.

(7) Zakharenko, V. A. Trends and Prospects of Chemical and Biological Plant Protection (in Russian). Protection and Quarantine of Plants 2011, 3, 6-10.

(8) Iqbal, N.; Bajwa, A. A.; Manalil, S.; Khan, A. M.; Kebaso, L.; Frimpong, D.; Ali, H. H.; Jha, P.; Chauhan, B. S. Biology and Management of Two Hordeum Weedy Species:
A Review.
Crop Protection
2019,
125,
104908. https://doi.org/10.1016/j.cropro.2019.104908. 
(9) Peredernova, V. M.; Vlasova, O. I.; Shutko, A. P. Allelopathic Properties of Weeds and Their Plant Residues in the Process of Mineralization. Scientific Journal KubSAU 2011, 73 (9), 1-11.

(10) Ali, K. W.; Shinwari, M. I.; Khan, S. Screening of 196 Medicinal Plant Species Leaf Litter for Allelopathic Potential. Pakistan Journal of Botany 2019, 51 (6), 2169-2177. https://doi.org/10.30848/PJB2019-6(43).

(11) Tsiaousi, A.; Vasilakoglou, I.; Gravalos, I.; Koutroubas, S. D. Comparison of Milk Thistle (Silybum Marianum) and Cardoon (Cynara Cardunculus) Productivity for Energy Biomass under Weedy and Weed-Free Conditions. European Journal of Agronomy 2019, 110, 125924. https://doi.org/10.1016/j.eja.2019.125924.

(12) Leclère, M.; Jeuffroy, M.-H.; Butier, A.; Chatain, C.; Loyce, C. Controlling Weeds in Camelina with Innovative Herbicide-Free Crop Management Routes across Various Environments. Industrial Crops and Products 2019, 140, 111605. https://doi.org/10.1016/j.indcrop.2019.111605.

(13) Spiridonov, Yu. Y.; Shestakov, V. G. The Practice of Creating and Effective Application of Combined Domestic Herbicides in Weed Control in Cereal Crops (in Russian). Agrochemistry 2013, 1, 35-49.

(14) Zakharenko, V. A. Scientific and Informational Support of Integrated Management of Phytosanitary Condition of Agroecosystems of Russia (in Russian). Protection and Quarantine of Plants 2016, 5, 8-11.

(15) Handbook of the Climate of the USSR (in Russian); Kuharskaya, V. L., Ed.; Voume 20. Tomsk, Novosibirsk, Kemerovo and Altai Territory. Part IV. Humidity, precipitation, snow cover; Hydrometeoizdat (Hydrometeorological Institute): Leningrad, 1969.

(16) Prosyannikova, O. I. Soil and agrochemical zoning and the use of fertilizers in the Kemerovo region (in Russian); Kuzbassvuzizdat: Kemerovo, 2007.

(17) Nikitin, V. V. Weed Plants of the USSR Flora (in Russian); Nauka: Leningrad, 1983.

(18) Luneva, N. N.; Mysnik, E. N. Modern botanical nomenclature of weed plant species of the Russian Federation.; Plant Protection News, Supplements; Zenodo, 2018; Vol. 26. https://doi.org/10.5281/zenodo.1241599.

(19) Beketova, O. A.; Starikova, E. A. Analysis of the Distribution of Weed Species in Segetal and Ruderal Habitats (in Russian). Bulletin of the KrasGAU 2016, 11, 3-9.

(20) Jaric, S.; Karadzic, B.; Vrbnicanin, S.; Mitrovic, M.; Kostic, O.; Pavlovic, P. Floristic and Phytocoenological Research of Segetal Plant Communities in Cultivated Areas of Southern Srem. Archives of Biological Sciences 2015, 67 (2), 591-609. https://doi.org/10.2298/ABS141017021J. 


\section{Information about Authors}

Ekaterina KONDRATENKO: D.Sc. in Agriculture, Professor, Kuzbass State Agricultural Academy; 5 Markovtsev Str., Kemerovo, 650056, Russia; e mail: library82@mail.ru.

Elena EGUSHOVA: Ph.D. in Engineering, Associate Professor, Kuzbass State Agricultural Academy; 5 Markovtsev Str., Kemerovo, 650056, Russia; e-mail: egushova@mail.ru.

Alexey STAROVOiTOV: Branch Manager, Branch of Russia Agricultural Center in the Kemerovo Region; 3 Kolomeytsev Str., Kemerovo, 650000, e-mail: rsc42@mail.ru.

Elena STAROVOITOVA: Chief Agronomist, Branch of Russia Agricultural Center in the Kemerovo Region; 3 Kolomeytsev Str., Kemerovo, 650000, e-mail: rsc42@mail.ru.

Iraida SERGeEVA: Ph.D. in Physics and Mathematics, Associate Professor, Kuzbass State Agricultural Academy; 5 Markovtsev Str., Kemerovo, 650056, Russia; e-mail: ira_sergeeva@mail.ru.

Ekaterina ROTKINA: Senior Lecturer, Kuzbass State Agricultural Academy; 5 Markovtsev Str., Kemerovo, 650056, Russia; e-mail: k.rot@mail.ru. 